\section{Influence of Strategic Knowledge Management on Firm Innovativeness and Performance}

\author{
Guillermo Davila ${ }^{1, t}$ \\ ${ }^{1}$ Universidade Federal de Santa Catarina, Florianópolis, SC, Brazil \\ Gregorio Varvakis ${ }^{2, \Omega}$ (D) \\ ${ }^{2}$ Universidade Federal de Santa Catarina, Florianópolis, SC, Brazil \\ Klaus North ${ }^{3, ¥}$ (D) \\ ${ }^{3}$ Hochschule RheinMain, Wiesbaden Business School, Alemanha
}

\section{ABSTRACT}

This paper identifies the type and intensity of relationships that exist between strategic knowledge management (SKM) practices, innovation performance and organizational Performance. By doing so, it covers theoretical gaps about the analysis of these relationships in emerging countries. Data was collected from a sample composed by 127 Southern Brazilian firms and PLS-SEM was used for testing the hypotheses. The relevance of SKM practices for innovation and organizational performance is supported. The research has also shown the level of efficiency and use of each SKM practice. The findings allow Brazilian practitioners to identify those actions which stronger influence on innovativeness and performance. The results also have shown that Brazilian firms are focused on management of explicit knowledge, and there are some opportunities for improving performance if they focus more on tacit knowledge. The suggestions about priority practices and managing of tacit knowledge are relevant contributions to support managerial decisions for resource allocation oriented to improve innovation and performance.

Keywords: Strategic knowledge management; Innovation; Organizational performance; Knowledge management practices; Brazil.

\section{INTRODUCTION}

Some scholars point out that the firm' competitive advantage is a function of the relationship between its knowledge and its innovation capability (NONAKA \& TAKEUCHI, 1995; ROMAN, 2012). Since knowledge is a key resource for firm innovativeness and competitiveness, it needs to be managed by creating and sustaining knowledge management practices (KM practices). KM practices are defined by Kianto and Andreeva (2014) as intentional and observable actions that aim to maximize the value generated by organizational knowledge assets.

Several studies have addressed the contribution of knowledge management for innovation in firms based in developed countries (OECD, 2003, MCKEEN et al., 2006, ZACK et al., 2009, ALEGRE et al., 2013, INKINEN et al., 2015), and others have focused their attention on the relationship between innovation and organizational performance (DARROCH, 2005; JANSEN et al., 2006).
Corresponding author:

${ }^{\dagger}$ Universidade Federal de Santa Catarina, Florianópolis, SC, Brazil

E-mail: davila.guillermo@gmail.com

${ }^{\Omega}$ Universidade Federal de Santa

Catarina, Florianópolis, SC, Brazil

E-mail: g.varvakis@ufsc.br

${ }^{¥}$ Hochschule RheinMain, Wiesbaden

Business School, Alemanha

E-mail: klaus.north@gmail.com

Received: 02/22/2018.

Revised: 05/03/2018.

Accepted: 07/23/2018

Published Online: 04/10/2019.

DOI: http://dx.doi.org/10.15728/bbr.2019.16.3.3 
In the Brazilian context, qualitative research has addressed the relationship between strategic KM practices and organizational performance using theoretical approaches (PONCHIROLLI, FOGLE, 2005), or empirical evidence from the textile sector (NORTH et al., 2013; DAVILA et al., 2016), health sector (JACQUES, KINGS, 2007) or technology parks (CRUZ, 2007). Other research has examined the relationship between knowledge absorptive capacity, innovation performance and organizational performance (DAVILA, 2018).

However, few studies have investigated the effects of knowledge-based resources on innovation and competitiveness in firms from Brazil or emerging countries (NAGANO et al., 2014; INKINEN et al., 2015). Specifically, the influence of SKM practices acting simultaneously on both firm innovation performance and organizational performance, has not been analyzed with a systemic approach. Due to this lack of attention, there is not yet a complete understanding of the nature of the relationships between these constructs and, consequently, several questions emerge about which SKM practices are the most appropriate and how they can improve both innovative and organizational performance of Brazilian firms.

In this context, the following questions arise: what is the influence of SKM practices on innovation performance, and the influence of these two variables on organizational performance? What are the most important SKM practices for innovative performance and organizational performance? Which SKM practices deserve more focus and priority when managers are allocating their resources?

This paper answers these questions by exploring together the relationship between the SKM practices, innovation performance and organizational performance. The results add to both knowledge management and innovation theories in emerging countries, and they provide concrete suggestions about priority SKM practices for Brazilian companies, considering their efficiency on performance.

We selected Brazil for two reasons. First, there is only limited coverage in the literature about the applicability and use of SKM practices in Brazil, and by closing this gap this paper will contribute to the general management theory and will respond to the claims presented in previous research (RODRIGUES et al., 2012). Second, Brazil is one of the emerging markets with a growing importance in the international arena, due to its economic growth, its well developed technological capabilities in some sectors and its recent policies for supporting industrial innovation (GEREFFI, 2017).

\section{THEORETICAL BACKGROUND}

\subsection{INNOVATION AND ORGANIZATIONAL PERFORMANCE}

In the business context, innovation is a key driver of competitive advantage, and ultimately, a source for the development of new or improved goods and services (SCHUMPETER, 1927). In the academic environment, innovation is being studied, as process or as a result, in various disciplines, for example: business administration, economics, technology, engineering (BAREGHEH et al., 2009). Schumpeter (1927) in his seminal work defines innovation as one or more of the following: the introduction of a new product or the improvement of an existing one, the introduction of a new production method or the improvement of an existing one, and the opening of a new market - all leading the firm towards a new economic condition.

Tidd and Bessant (2005) posit that sustainable performance of firms is related to their ability to manage innovations. They point out that this ability can be improved through learning in two ways (p. 591): i) acquisition of new knowledge (technological, regulatory, marketing) to be added to the firm's knowledge base, and so, for its use in both new or improved products and processes; that's what Cohen and Levinthal (1990) named knowledge absorptive capacity; ii) knowledge about the innovation process itself, this means the ability 
BBR

16,3

to develop and operate the set of required routines for managing innovation (COHEN \& LEVINTHAL, 1990). This is also defined by Wang et al. (2013) as 'meta-knowledge', which is used for the production of new knowledge.

Thus, a proper selection of knowledge management practices can help organizations to take advantage of both: knowledge embedded in the innovation process and the 'meta-knowledge' about the process itself.

\subsection{KNOWLEDGE MANAGEMENT PRACTICES}

How is knowledge management related to the firm operation? For CEN (2004), KM practices are the link between the KM process cycle and the strategic goals of the firm. Research conducted by the OECD (2003) concluded that the implementation of KM practices is a critical phase for organizational change towards a knowledge-based economy.

A study by Kianto and Andreeva (2014) defined KM practices as a set of managerial actions intentionally performed that support organizational knowledge processes, in order to maximize the value generated by organizational knowledge assets. Academics posit that a subset of the listed practices by Kianto and Andreeva (2014), called SKM practices, include the required activities for identifying the most important knowledge-based strategic assets, for creating a knowledge-based strategy, for acquiring this knowledge, for facilitating its use, and for assessing it constantly (INKINEN et al., 2015; KIANTO et al., 2018). According to the knowledge-based view of firm (KBV), the competitive advantage is defined by how firms integrate, develop and apply their critical knowledge (GRANT, 1996). Thus, SKM practices are a source of competitive advantage, since they allow firms to manage intangible assets that can lead to the effective value creation based on knowledge, and can lead to redefining their own value creation activities (KIANTO et al., 2018). Such SKM practices include: the understanding of the current organizational knowledge, the identification of the most relevant knowledge and skills, the systematic assessment of these elements to identify gaps, the benchmarking to acquire missing knowledge that is possessed by foreign agents, the development of a clear strategy (and integrated into the strategic planning) to develop such knowledge (KIANTO and ANDREEVA, 2014) (see table 1). Results of previous research in various contexts have demonstrated the importance of SKM practices for organizational competitiveness (KIANTO and ANDREEVA, 2014; INKINEN et al., 2015), and for this reason, these practices are focus of this study.

\subsection{ENVIRONMENTAL FACTORS THAT INFLUENCE THE USE AND EFFICIENCY OF KNOWLEDGE MANAGEMENT IN BRAZILIAN ORGANIZATIONS.}

The level of use and efficiency of SKM practices can vary depending of the context (SERGEEVA, ANDREEVA, 2016), because it defines the 'rules of the game', thus, the formal and informal constraints for both management activities and human interactions (PENG, 2002). Research about KM in the Brazilian business environment (PAIVA, ROTH, FENSTERSEIFER, 2008, DOMINGUEZ GONZALEZ, MARTINS, TOLEDO, 2014, DAVILA et al., 2018) posits that 'knowledge' is a key competitiveness factor, it can be transferred and is more likely to be perceived when it is explicit (e.g. embedded in technology). This evidence is in line with the $\mathrm{KBV}$, which posits that the primary role of organizations is to integrate the specialized knowledge possessed by individuals into the final goods and services (GRANT, 1996).

Following Davila et al. (2018), we describe a subset of environmental factors that are relevant for our study, because of their potential influence on both the use and efficiency of SKM practices in Brazilian organizations. Such factors are related to national culture, business context and organizational' internal structure: 
Table 1 - Results of assessment of the measurement model.

\begin{tabular}{|c|c|c|c|c|c|c|c|c|}
\hline Construct & Ind. & Item wording & Mean & loadings & $\begin{array}{l}\text { Cronbach's } \\
\text { Alpha }\end{array}$ & rho_A & $\begin{array}{l}\text { Comp. } \\
\text { Reliab. }\end{array}$ & AVE \\
\hline \multirow{6}{*}{$\begin{array}{l}S \mathrm{t} \text { a t e g i c } \\
\text { Management of } \\
\text { Knowledge }\end{array}$} & GE1 & $\begin{array}{l}\text { Our organization has a clear } \\
\text { understanding of our current core } \\
\text { knowledge }\end{array}$ & 3.70 & 0.79 & 0.88 & 0.89 & 0.91 & 0.64 \\
\hline & GE2 & $\begin{array}{l}\text { Our organization has a clear } \\
\text { view of what knowledge and } \\
\text { competences are the most relevant } \\
\text { for the objectives }\end{array}$ & 3.71 & 0.84 & & & & \\
\hline & GE3 & $\begin{array}{l}\text { Our organization's knowledge } \\
\text { and competences are evaluated } \\
\text { systematically }\end{array}$ & 3.08 & 0.77 & & & & \\
\hline & GE4 & $\begin{array}{l}\text { Our organization benchmarks our } \\
\text { strategic knowledge against that of } \\
\text { our competitors. }\end{array}$ & 2.95 & 0.73 & & & & \\
\hline & GE5 & $\begin{array}{l}\text { Our organization explicitly } \\
\text { recognizes knowledge as a key } \\
\text { element in the strategic planning } \\
\text { exercises. }\end{array}$ & 3.87 & 0.78 & & & & \\
\hline & GE6 & $\begin{array}{l}\text { Our organization has a clear } \\
\text { strategy for developing knowledge } \\
\text { and competences. }\end{array}$ & 3.17 & 0.87 & & & & \\
\hline \multirow{12}{*}{$\begin{array}{l}\text { Organizational } \\
\text { Performance }\end{array}$} & DO1 & $\begin{array}{l}\text { Compared with the industry } \\
\text { average, we are growing more } \\
\text { rapidly. }\end{array}$ & 3.47 & 0.69 & 0.84 & 0.85 & 0.89 & 0.61 \\
\hline & $\mathrm{DO} 2$ & $\begin{array}{l}\text { In general, our organization is } \\
\text { performing better than it did } 12 \\
\text { months ago. }\end{array}$ & 3.91 & 0.70 & & & & \\
\hline & DO3 & $\begin{array}{l}\text { In general, our organization is } \\
\text { performing better than it did five } \\
\text { years ago. }\end{array}$ & 4.14 & 0.77 & & & & \\
\hline & DO4 & $\begin{array}{l}\text { Over the past } 12 \text { months, } \\
\text { our organization has met its } \\
\text { performance objectives. }\end{array}$ & 3.58 & 0.86 & & & & \\
\hline & DO5 & $\begin{array}{l}\text { Over the past five years, } \\
\text { our organization has met its } \\
\text { performance objectives. }\end{array}$ & 3.75 & 0.87 & & & & \\
\hline & DO6 & $\begin{array}{l}\text { Compared with the industry } \\
\text { average, we are more profitable. }\end{array}$ & \multicolumn{2}{|c|}{ Excluded } & & & & \\
\hline & DO7 & $\begin{array}{l}\text { Compared with the industry } \\
\text { average, we have a greater market } \\
\text { share. }\end{array}$ & \multicolumn{2}{|c|}{ Excluded } & & & & \\
\hline & IPD & $\begin{array}{l}\text { Compared to our competitors, our } \\
\text { company has been successful in } \\
\text { creating innovations in Products } \\
\text { and services for customers }\end{array}$ & 3.67 & 0.82 & 0.88 & 0.89 & 0.91 & 0.68 \\
\hline & IPR & $\begin{array}{l}\text { Compared to our competitors, our } \\
\text { company has been successful in } \\
\text { creating innovations in Production } \\
\text { methods and processes }\end{array}$ & 3.73 & 0.77 & & & & \\
\hline & IPG & $\begin{array}{l}\text { Compared to our competitors, } \\
\text { our company has been successful } \\
\text { in creating innovations in } \\
\text { Management practices }\end{array}$ & 3.74 & 0.85 & & & & \\
\hline & IPM & $\begin{array}{l}\text { Compared to our competitors, our } \\
\text { company has been successful in } \\
\text { creating innovations in Marketing } \\
\text { practices }\end{array}$ & 3.22 & 0.75 & & & & \\
\hline & IMO & $\begin{array}{l}\text { Compared to our competitors, our } \\
\text { company has been successful in } \\
\text { creating innovations in Business } \\
\text { models }\end{array}$ & 3.58 & 0.91 & & & & \\
\hline
\end{tabular}

S t r a t e g i c Management of Knowledge strategic knowledge against that of Our organization explicitly recognizes knowledge as a key element in the strategic planning Compared with the industry average, we are growing more In general, our organization is performing better than it did five Over the past 12 months, our organization has met its nance objectives. Compared with the industry average, we are more profitable. average, we have a greater market Compared to our competitors, our company has been successful in creating innovations in Products creating innovations in Production

Compared to our competitors,

Source: Results of this study. 
BBR

16,3

I. Brazilian national culture has a high in-group collectivism, thus, high levels of commitment, sense of belonging and loyalty on group level, that facilitate informal interactions for knowledge sharing. On the other hand, the high power distance in Brazilian national culture may mitigate workers motivation for both sharing and applying knowledge, because of the workers propensity for following the leaders' orders (HOUSE et al., 2004).

II. Talking about the most relevant contextual factors, it is pertinent to highlight that the economy instability tend to create a need for innovation (ALVES FILHO et al., 2015) and motivates workers to adapt to new methods, in order to being useful for the organization (STRATEGIC DIRECTION, 2005). On the technological side, during the last years, Brazil started a set of laws for developing both research and technology development. These laws also helped to improve workers' abilities for using and dealing with technology (SPARKMAN, 2015).

III. On the intra-organizational side, Brazilian businesses tend to use high amounts of information from customers and less information from suppliers, during their competitive intelligence activities (PAIVA et al., 2012). For this reason, strategic alliances are seen as a source of knowledge and growth (FLEURY and FLEURY, 1997). These features are relevant for this study, and ultimately, they are an important source for the analysis and discussion of our results.

\subsection{THE RELATIONSHIP BETWEEN SKM PRACTICES AND INNOVATION PERFORMANCE.}

The study by Gloet \& Terziovski (2004), using 70 firms from Australia and New Zealand, identified a positive relationship between innovation performance and KM practices, specifically practices based on both human resource management and information technologies. In recent years, Alegre et al. (2013) obtained similar results, by analyzing a group of French biotechnology SMEs. SKM practices and their impact on organizational performance, has become one of the new focus of interest among scholars (e.g. ALEGRE et al., 2013; KIANTO, ANDREEVA, 2014; INKINEN et al., 2015). The research by Githii (2014) concludes that SKM practices related to leadership, policies and strategy, promote firm' innovation performance. Inkinen et al. (2015) analyzed Finnish organizations and found that the application of SKM practices influences firm innovation performance. Considering cited studies in this section, this paper is going to verify the follow hypothesis:

H1. The more intensive the use of SKM practices, the greater the innovation performance of the firm.

\subsection{THE RELATIONSHIP BETWEEN SKM PRACTICES AND ORGANIZATION- AL PERFORMANCE.}

Previous studies in Europe and North America (OECD, 2003; McKEEN et al., 2006; ZACK et al., 2009), found a positive relationship between KM practices and organizational performance. Similarly, a study by Supyuenyong and Swierczek (2011) using Thai firms found that KM practices related to codification, storage, recuperation and use of knowledge, have a direct and positive influence on organizational performance.

A more recent empirical research also reinforces the existence of a direct and positive influence of KM practices on organizational performance (GHOLAMI et al., 2013). In their research, Gholami et al. (2013) conclude that the improvement of KM practices is important for improving productivity, financial performance, worker performance, innovation, work relationships and customer satisfaction, in other words, organizational performance.

The evidence presented here is about how organizational performance as a whole is improved by the use of KM practices. Regarding SKM practices, the research by Kianto \& 
Andreeva (2014) is one of the few studies that identifies the positive impact of these kind of practices on organizational performance, specifically for improving sales and efficiency in time and cost. Considering the statements presented in this section, this study will discuss the following hypothesis:

H2. The more intensive the use of SKM practices, the greater the organizational performance of the firm.

\subsection{INNOVATION PERFORMANCE AND ORGANIZATIONAL PERFORMANCE}

Measuring innovation and analyzing its consequences is a challenge, due to some difficulties. Both, incomes and outcomes of innovation are difficult to identify clearly. The number and complexity of other internal variables affect the organizational behavior. Organizational scorecards have addressed financial markets by showing both technological and management efficiency instead of innovation indexes. Due to these aspects, some scholars propose to look at correlations between key indicators, such as new products, patents, investments in R\&D, productivity growth, profitability of stock market companies (TIDD and BESSANT, 2005). Other classical studies (DESS and ROBINSON, 1984, ROMIJN and ALBALADEJO, 2002) and recent (HUANG et al., 2016, INKINEN et al., 2015) in administration, economics and marketing areas, showed the feasibility of subjective indicators for analyzing these concepts.

Most research about innovation performance and organizational performance has identified a positive relationship between those constructs. For example, the study by Damanpour et al. (1989) highlights the importance of technical innovations for organizational performance. It also concludes that administrative innovations are necessary to facilitate technical innovations over the long term. Similarly, Jimenez-Jimenez and Sanz-Valle (2011) verified that organizational performance is directly and positively influenced by innovation performance. Akgun et al. (2009) have analyzed the types of innovation and they conclude that product innovations and process innovations have a strong and significant influence on organizational performance. Jansen et al. (2006) observed that the exploratory innovations are likely to increase financial performance of organizational units operating in dynamic environments. Based on these studies and other recent empirical studies (HUANG et al, 2016, JURKIENE and GINUWINE, 2015), this paper also tests the following hypothesis:

H3. The better the innovation performance of the organization, the better its organizational performance.

\section{METHOD}

In line with our positivist approach, this study uses quantitative methods, which have been already used in relevant research about knowledge and innovation in many countries (GLOET and TERZIOVSKI, 2004, KIANTO and ANDREEVA, 2014, INKINEN et al., 2015). Additionally, we believe that positivism is the most appropriate approach to conduct studies in the Brazilian context, because it considers knowledge as a resource that can be transferred, and that is usually related to both technology and value creation (PAIVA, ROTH, FENSTERSEIFER, 2008, DOMINGUEZ GONZALEZ, MARTINS, TOLEDO, 2014).

\subsection{SAMPLE AND DATA COLLECTiON}

This paper analyses organizations based in Santa Catarina State, a state that is responsible for $5 \%$ of the Brazilian GDP, employing $7.8 \%$ of Brazilian work force and that has the fourth largest GDP per capita in Brazil (IBGE, 2014). The choice for Santa Catarina is justified because it is an innovative state, the most industrialized one in Brazil (31\% of 
the State's GDP come from industrial sectors), with a diversified economy that is driven by a group of main sectors: food and beverages, metal mechanics, textiles, ICTS, ceramics, minerals and tourism (SEBRAE, 2017).

Numbers from FIESC (2016) show that organizations in Santa Catarina are constantly investing, especially in technology, machinery and equipment. During 2015, food and beverage sector led the investments in Santa Catarina (38\% of the total of food companies made new investments during 2015), followed by the sector of electric equipment and materials $(24 \%)$.

Surveyed companies have been selected from a database of the Industry Federation of Santa Catarina State (FIESC/SC). Data collection was carried out between November 2015 and March 2016, using an online tool. By sending e-mails, we invited managers from strategic or tactical levels from 1548 organizations to participate in the research. As a result of the data collection efforts, 147 responses were collected, representing a response rate of $9.5 \%$.

This paper aimed to analyze organizations that use SKM practices in an intentional and systematic way. For this reason, we selected organizations with 20 or more employees, following criteria used in previous research (JANSEN et al., 2007). Jennings and Beaver (1997) conclude that in companies with 20 or more employees the owner begins to divide responsibilities and adopts a more professional management. By applying this criterion, we excluded 20 organizations and the final sample was 127 answers.

The main industrial sectors in Santa Catarina (SEBRAE/SC, 2013) are represented in the final sample (FIESC, 2016). Thus, the most represented sectors were food and beverages $(32 \%)$, textiles $(18 \%)$ and capital goods $(8 \%)$. The sample also reflects the predominance of small and medium-sized firms (SMEs) in Santa Catarina, as evidenced by FIESC (2016). Most organizations in the sample employ between 20 and 100 employees (44\%). Organizations with 500 employees or more were the second most represented (29\%) group. In addition, $27 \%$ of the organizations in the sample are between 101 and 499 employees.

A significant number of respondents belong to strategic $(41 \%)$ or tactical $(42 \%)$ positions. The other respondents were nominated by their respective strategic leaders, and these respondents, with few exceptions, have supervisory positions or are key specialists in their organizations.

\subsection{SCALES}

The scale by Kianto and Andreeva (2014) was used to measure SKM practices. It has been used in other related research (INKINEN et al., 2015).

We measured innovation performance using the scale presented by Inkinen et al. (2015). The scale compares firm's performance against its competitors, by using five items: product, process, managerial practices, marketing and business model innovations.

Finally, we used the scale developed by Darroch (2005) to measure organizational performance. The scale has seven items for assessing performance-related elements, such as profitability, market participation, growth, achievement of goals and internal performance.

The online survey had a Likert scale of 5 points, with values from "1-strongly disagree" up to "5-totally agree ". The items assessed in the survey are presented in table 1.

As suggested by Chandy and Tellis (2000), we included two control variables: the firm's age (years) and size of firm (number of employees), by using logarithmic transformation of these indicators to bring them closer to a normal distribution. 


\subsection{Method of Analysis}

We tested hypotheses using structural equation modelling (SEM), a technique that su16,3 pports the analysis of causal relationships between variables. SEM fits to this research because it is appropriate for both studies with small sample-size or with at least one variable that does not follow a normal distribution (HAIR et al., 2006; HENSELER et al., 2016). We used the SmartPLS software version 3.2.7 for data analysis, since the tool gives a proper support for SEM, according to Henseler et al. (2016). First, we developed a measurement model and tested for ensuring reliability, convergent and discriminant validity in all constructs (HENSELER et al., 2016).

After validating the measurement model, we assessed the structural model. The Standardized Root Mean Residual (SRMR) was calculated, defined by Henseler et al. (2016) as the difference between the observed and expected correlation. Thereafter, the adjusted $\mathrm{R}^{2}$ value was determined in order to identify which $\mathrm{h}$ percentage of innovative performance and organizational performance can be explained by the model. Then, we executed a bootstrapping procedure (with 5,000 samples) to obtain the coefficients, confidence intervals and statistical significance of each tested hypothesis.

The effect size $\left(\mathrm{f}^{2}\right)$ was assessed to quantify how important are the significant effects, according to Cohen (2013). Large, medium and small $\mathrm{F}^{2}$ values are represented by values above $0.35,0.15$ and 0.02 respectively. Finally, we performed the blindfolding procedure to check the predictive model relevance, by verifying that $\mathrm{Q}^{2}$ values are above 0 (STONE, 1974, GEISSER, 1975).

\section{RESULTS}

This section presents the results of the assessment and measurement model of the structural model, which allow testing the hypotheses proposed in this study.

\subsection{Measurement MOdel}

The reliability of constructs was assessed by using Cronbach's Alpha, composite reliability and rho A tests, following suggestions by Henseler et al. (2016). Two indicators were removed as they have loadings below the accepted threshold of 0.7 suggested by Nunnally and Bernstein (1994) $(\mathrm{OP} 1=0.569$, e OP2 $=0.605)$. After the second evaluation, the model showed acceptable validity and reliability indicators, above the recommended thresholds, as shown in table 1.

Following Fornell and Larcker (1981), we checked that the average variance extracted (AVE) of each construct was above 0.5 , in order to assure an appropriate convergent validity. The convergent validity of the indicators was verified, by checking that the indicator loadings of each construct was higher than 0.65 , as suggested by Hair et al. (2006).

The model showed a discriminant validity, by verifying that the root square of the AVE for each construct is greater than the construct correlation with each other (HENSELER et al 2016), as shown in Table 2.

Table 2 - Correlations between constructs

\begin{tabular}{llll}
\hline & Innovation Performance & Organizational Performance & $\begin{array}{l}\text { Strategic Management Of } \\
\text { Knowledge }\end{array}$ \\
\hline Innovation Performance & 0.822 & & \\
Organizational Performance & 0.476 & 0.781 & 0.797 \\
Strategic Management of Knowledge & 0.522 & 0.448 & \\
$\left(^{*}\right)$ Correlations between constructs, square root of AVE in diagonal. & & \\
\hline
\end{tabular}

Source: Results of this study. 
BBR

16,3

The assessment showed that the measurement model is reliable and valid to represent the concepts discussed in this study. Then, we assessed the structural model.

\subsection{Structural Model}

The model used to test the hypotheses (shown in Figure 1) showed an index of 0.077 SRMR, below the maximum threshold of 0.10 suggested by Henseler et al. (2016).

Figure 1 - Structural model of this study

Strategic Knowledge

Management Practices

Innovation Performance

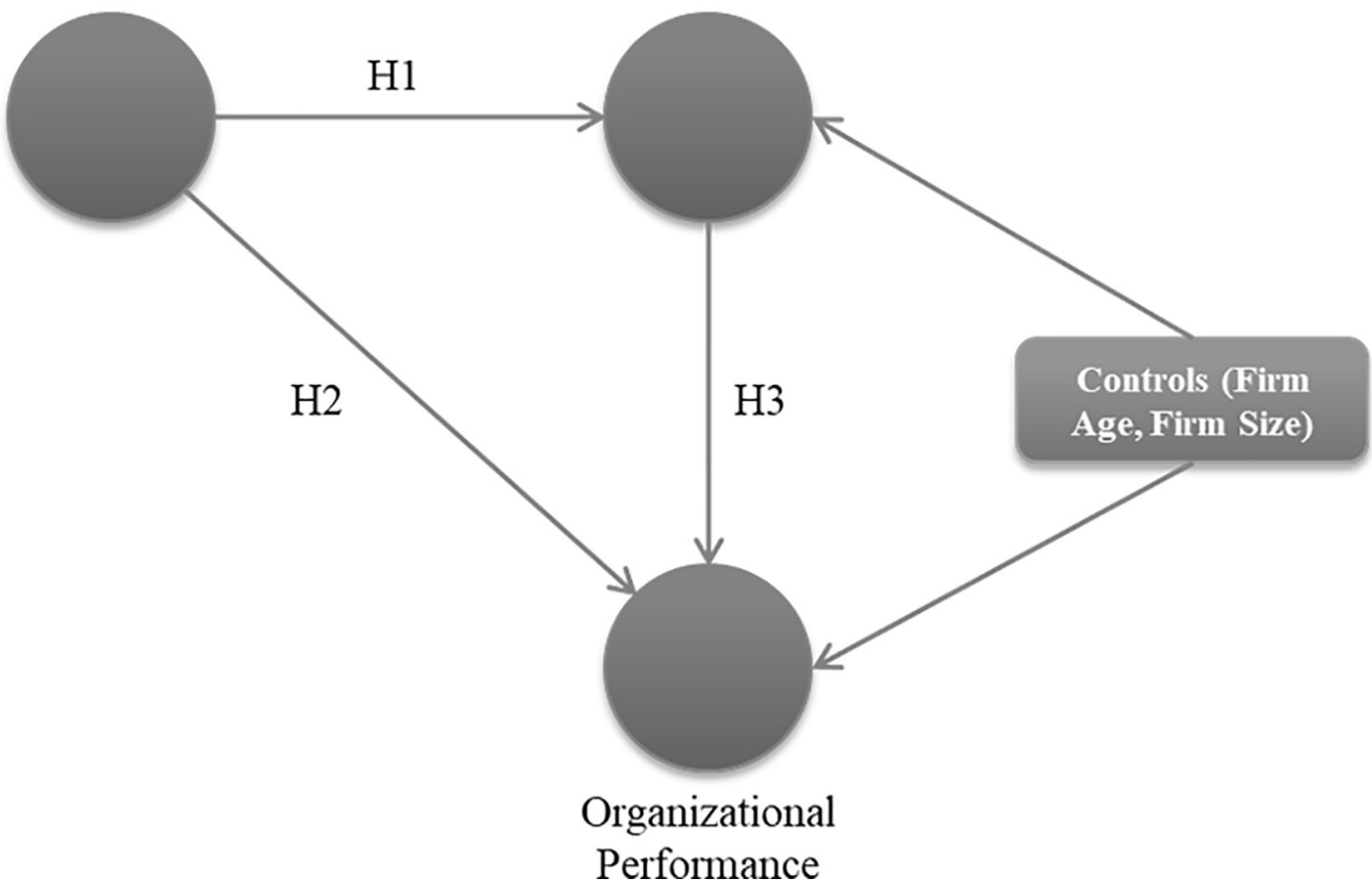

Source: Mann and Sahni (2015)

Table 3 presents the adjusted- $\mathrm{R}^{2}$ values, which indicate the proportion of variability explained by the model (Henseler et al., 2016). Thus, it is possible to conclude that the model explains $26.2 \%$ of innovation performance and $30 \%$ of organizational performance.

Table 3 - $\mathrm{R}^{2}$ and $\mathrm{Q}^{2}$ values

\begin{tabular}{lcccc}
\hline \multirow{2}{*}{ Construct } & \multirow{2}{*}{$\mathrm{R}^{2}$} & \multicolumn{2}{c}{ Adjusted $\mathrm{R}^{2}$} & $\mathrm{Q}^{2}$ \\
\cline { 3 - 4 } & & $\mathrm{R}^{2}$ & sign $(\mathrm{p})$. & 0.000 \\
Innovation Performance & 0.280 & 0.262 & 0.487 \\
Organizational Performance & 0.322 & 0.300 & 0.000 & 0.413 \\
\hline
\end{tabular}

Source: Results of this study.

After running the procedure of bootstrapping, empirical evidence supports the three hypotheses ( $\mathrm{H} 1, \mathrm{H} 2$ and $\mathrm{H} 3)$. The results suggest the existence of significant paths between SKM practices and innovative performance $(0.52, \mathrm{p}<0.01)$, SKM practices and organizational performance $(0.281, \mathrm{p}<0.01)$, innovation performance and organizational performance $(0.310, \mathrm{p}<0.01)$ as presented in table 4 . 
Table 4 - Estimated paths, $\rho$ values and $\mathrm{f}^{2}$ values.

\begin{tabular}{|c|c|c|c|c|c|}
\hline Hypotheses & $\beta$ coef. & Stand. Dev. & $\operatorname{sign}(\rho)$. & $\mathrm{f}^{2}$ & Result \\
\hline H1. SKM practices -> Innovation Performance & $0.520^{* *}$ & 0.071 & 0.000 & 0.376 & Accepted \\
\hline $\begin{array}{l}\text { H2. SKM practices } \rightarrow \quad \text { Organizational } \\
\text { Performance }\end{array}$ & $0.281^{* *}$ & 0.096 & 0.003 & 0.085 & Accepted \\
\hline $\begin{array}{l}\text { H3. Innovation Performance }->\text { Organizational } \\
\text { Performance }\end{array}$ & $0.310^{* *}$ & 0.102 & 0.002 & 0.102 & Accepted \\
\hline \multicolumn{6}{|l|}{ Effects of controls } \\
\hline Firm age $->$ Innovation Performance & -0.066 & 0.080 & 0.409 & 0.005 & \\
\hline Firm age -> Organizational Performance & -0.131 & 0.072 & 0.070 & 0.019 & \\
\hline Firm size $->$ Innovation Performance & -0.026 & 0.098 & 0.790 & 0.001 & \\
\hline Firm size -> Organizational Performance & -0.104 & 0.075 & 0.168 & 0.012 & \\
\hline
\end{tabular}

Source: Results of this study.

In addition, following Cohen (2013), the model shows a large $\mathrm{f}^{2}$ (effect size) for H1, and a medium $\mathrm{f}^{2}$ in $\mathrm{H} 2$ and $\mathrm{H} 3$. Finally, the blindfolding procedure calculated the $\mathrm{Q}^{2}$ values $>$ 0 for all exogenous constructs (see table 3 ), and this evidenced a good predictive capacity.

Table 4 also shows that the control variables (age and firm size) does not have significant influence on endogenous constructs of the model $(\mathrm{p}>0.05)$ and they have small $\mathrm{f}^{2}$ values.

\section{DISCUSSION}

This study contributes to management studies, specifically with the KBV, by improving the understanding of the role of SKM practices for improving both innovation and organizational performance; and by proposing concrete suggestions for Brazilian firms to improve their competitiveness based on a better integration of their specialized knowledge.

\subsection{EVIDENCE ABOUT KNOWLEDGE MANAGEMENT IN BRAZILIAN FIRMS}

Firstly, we note that there are significant opportunities for improving performance of Brazilian companies, if they improve their strategic knowledge management. This study helps in the understanding of 'how' by showing the existence of three SKM practices with low usage, but with a high statistical loading, i.e. the indicator has a high influence on the construct that it represents, and ultimately, on both innovation and organizational performance constructs (see table 1).

More specifically, the practice GE4 - benchmarking to compare the company's strategic knowledge with the competitors - had the lowest average usage. One explanation may be the preference that Brazilian companies have for customers as sources of information (PAIVA et al., 2012). Applying knowledge benchmarking requires the existence of two capabilities inside the organization: First, the proper identification and management of tacit knowledge, which is not documented, is located inside people's minds and transmitted through informal conversations. Second, information search routines that allow both, bringing and storing this tacit knowledge from competitors, but also from the suppliers and the customers.

Other two practices with low frequency of use are: GE3 - systematic evaluation of organizational skills and knowledge, and GE6 - to have a clear strategy to develop these skills and competencies. Of course, the implementation of the GE3 is a prerequisite for GE6. The practice GE3 needs for the implementation of routines that allow the firm to collect skills 
BBR

16,3

and knowledge possessed by the employees (usually tacit), for those elements being evaluated later. The practice GE6 is part of a learning process based on the results of the knowledge assessment, specifically considering the gap between the current situation of strategic knowledge and the desired situation needed to reach the strategic objectives. Again, the greatest challenge for the deployment of the two practices (GE3 and GE6) is to understand tacit knowledge and to develop routines for managing it.

The evidence presented here suggests that Brazilian firms are managing technology and not tacit knowledge. They need both, to learn how to manage tacit knowledge, and to connect these managerial actions with strategic objectives. Rules and directives issued by the experts for enhancing knowledge integration, and not understood as an exercise of managerial authority (HOUSE et al., 2004), can facilitate the elicitation process of tacit knowledge, the first step for improving its management (GRANT, 1996).

Thus, the deployment of KM plans and routines can be facilitated by both the high in-group collectivism in Brazilian national culture (HOUSE et al., 2004) and the high propensity of Brazilian workers adapting to new methods of work (STRATEGIC DIRECTION, 2005). According to the KBV, a team-based organization emerges as an alternative for Brazilian companies improving their cooperation and coordination capacities (GRANT, 1996). The team-based structure can be a facilitator for the implementation of both group problem-solving and collaborative decision making, highlighted by the KBV as coordination mechanisms that increase the firm's common knowledge, promote knowledge transfer and, consequently, improve organizational efficiency.

The policies implemented by Brazil in recent years for promoting the development of technology, R\&D and innovation (SPARKMAN, 2015), can be even more efficient in terms of support to value creation, when combined with a national education system that considers the development of skills for knowledge application, a key process according to KBV. Currently, knowledge management is not explicitly included in national documents, such as the "Law of Guidelines and Basis for National Education". In the short term, a suitable alternative for businesses can be the use of own corporate education services or accessible via strategic alliances (SPARKMAN, 2015).

\subsection{SKM PRACTICES AND INNOVATION PERFORMANCE}

The influence of SKM practices on innovative performance evidenced in this study supports the findings of various papers presented in the literature (INKINEN et al., 2015; GITHII; 2014; LOPÉZ-NICOLÁS, MERONO-CERDÁN, 2011). In this research, two indicators show the greatest loadings on the SKM practices construct (see table 1), and they seem to be the most important ones: GE2- to identify both the knowledge and the skills most relevant to business goals, and -GE6- to have a clear strategy to develop these skills and competencies.

These results are in line with the work by López-Nicolás and Merono-Cerdán (2011) that highlights the importance of knowledge maps as a starting point to innovate from KMbased strategies. This research also showed that companies that consider knowledge and skills as part of their strategic planning tend to be more innovative, in line with previous results in Finland (INKINNEN et al., 2015). During planning processes, a look 'beyond the limits of the company' to identify and to acquire relevant knowledge from customers and suppliers, brings opportunities for gains on innovative capabilities, as confirmed in previous studies in the food industry in Brazil (NOGUEIRA et al., 2014).

The results presented here show a direct influence of SKM on innovation performance, in contrast to other studies that highlight the need of an organizational capacity mediating this relation (ALEGRE et al., 2013). This discrepancy creates the need for more detailed analysis that can be conducted in future research. 


\subsection{SKM PRACTICES AND ORGANIZATIONAL PERFORMANCE}

Similar to previous research (OECD, 2003; MCKEEN, 2006; ZACK, 2009; 16,3 SUPYUENYONG and SWIERCZEK, 2011; KIANTO and ANDREEVA, 2014), this study evidenced an influence of SKM practices on organizational performance. Specifically, the loadings of indicators DO4 and DO5 (see table 1) seem to show that the companies analyzed are using SKM practices to achieve performance objectives. In this context, the low use of benchmarking of competitors' knowledge (indicator GE4) shows that a greater focus in the use of this practice may bring opportunities for businesses in Santa Catarina improving their performance. In effect, textile companies using joint innovation projects, which included activities for knowledge benchmarking, have improved organizational performance in a sustainable way (DAVILA et al., 2016).

The use of joint innovation projects or any kind of strategic alliances is recommended by $\mathrm{KBV}$ as a mechanism that allows firms to increase the efficiency of knowledge application when there is no full congruence between the organizational domain of knowledge and the product domain of knowledge (GRANT, 1996). Brazil has a favorable environment for this kind of initiatives, because it has economic policies that foster joint projects of R\&D and innovation (NOGUEIRA et al., 2014, SPARKMAN, 2015).

The survey also showed that two of the seven indicators for measuring organizational performance (D06 and DO7), which assess growth and profitability, did not achieve the minimum correlation threshold to other indicators of construct, and they were withdrawn for lack of statistical reliability. This may be explained by the turbulent economic context experienced by Brazilian organizations from the year 2015.

\subsection{INNOVATION PERFORMANCE AND ORGANIZATIONAL PERFORMANCE}

The results of this study are in line with recent studies that show that innovation plays an important role for both innovative and organizational performance (DARROCH 2005, HUANG et al., 2016). Brazilian companies perceive innovation as a source of competitiveness, and they invest intensively on innovation projects, including research activities, technology and machinery (FIESC, 2016). According to FIESC (2016), the food and beverage sector led the investments in innovation in Santa Catarina during 2015. This repeated behavior can explain the fact that this sector possesses a value added in Brazil that grows faster than the value added of the whole economy (WIJNANDS et al., 2007).

Another interesting finding is that Brazilian companies are more likely to innovate in processes, managerial practices and products (see numbers in table 1). This correlation between product and process innovations in Brazilian companies is supported by previous research showing an increased effect on sales growth when product and process innovations happen simultaneously (GOEDHUYS, VEUGELERS, 2012). Typically, process innovations are driven by the need to operate at full capacity, and these are more likely to happen in intensive production companies (PAVITT, 1984), by identifying barriers that when fixed increase the organizational performance. Furthermore, in line with the findings by Pavitt (1984), this study showed that the internal performance is the indicator with the biggest loading on organizational performance construct (see annex).

It was noted also that product innovation has the greatest load on the construct of innovation performance (see table 1). The explanation can be found in the work of Pietrobelli and Rabellotti (2011), which showed that Brazilian companies are constantly adapting their product designs to local environments (phenomenon called 'tropicalization') instead to initiate projects for the development of completely new products, which may require major changes (innovations) in processes, marketing and business model. 


\section{CONCLUSIONS}

The present study found that SKM practices influence both innovative performance and organizational performance in Brazilian companies. The findings discussed showed that Brazilian companies:

- Should improve the management of tacit knowledge, as a complementary skill for other capabilities they already have (related to acquisition and application of knowledge 'embedded' on technology, or explicit knowledge).

- Are more likely to improve their performance, if they identify the knowledge and the skills that are most relevant to business goals (indicator GE2), and if they have a clear strategy to develop these skills and competencies (GE6).

- Must implement routines for knowledge benchmarking, in order to compare the company's strategic knowledge against competitors' knowledge (GE4).

These findings contribute to the KBV, by identifying the role of both knowledge and critical assets for improving performance in organizations based in an emerging country. By doing so, this study helps to close a gap identified in recent studies (NAGANO et al., 2014; INKINEN et al., 2015).

The identification of priority SKM practices is going to support decisions made by managers of Brazilian companies, or companies wishing to operate in Brazil, for a better allocation of resources (habitually limited), in order to improve the efficiency in knowledge application and, consequently, in performance.

Finally, this study has some limitations that open new paths for further interdisciplinary research. New qualitative studies can be conducted to explain processes of knowledge creation and knowledge sharing that supports innovations in Brazilian companies; thus, non-static elements that were not scope of this study and that can hardly be explained by using a positivist approach (NONAKA and PELTOKORPI, 2006). Other Brazilian States can be analyzed and contextual variables that potentially influence the relationship between SKM practices and performance may be added. Further research can include more than one respondent per organization, considering more than one measurement during the data collection process. Finally, objective measures for assessing organizational performance can also be used.

\section{ACKNOWLEDGMENTS}

This study was financed in part by the Coordenação deAperfeiçoamento de Pessoal de Nível Superior - Brasil (CAPES) - Finance Code 001

\section{REFERENCES}

ALVES FILHO, A.; NOGUEIRA, E.; BENTO, P. Operations strategies of engine assembly plants in the Brazilian automotive industry. International Journal of Operations \& Production Management, v. 35 , n. 5, p. 817-838, 2015.

AKGUN, A., KESKIN, H., BYRNE, J. Organizational emotional capability, product and process innovation, and firm performance: An empirical analysis. Journal of Engineering and Technology Management, v.26, n.3, p.103-130, 2009.

BAREGHEH, A., ROWLEY, J., SAMBROOK, S. Towards a multidisciplinary definition of innovation. Management decision, v.47, n.8, p.1323-1339, 2009.

CHANDY, R.; TELLIS, G. The incumbent's curse? Incumbency, size, and radical product innovation. Journal of marketing, v. 64, n. 3, p. 1-17, 2000.

COHEN, J. Statistical Power Analysis for the Behavioral Sciences. New York: Taylor \& Francis, 2013.

COHEN, W., LEVINTHAL, D. Absorptive capacity: a new perspective on learning and innovation. Administrative science quarterly, v.35, n.1, p.128-152, 1990.

CRUZ, C. Gestão Estratégica do Conhecimento: estudo exploratório em empresas instaladas nos parques tecnológicos do estado de São Paulo. 2007. Tese de Doutorado. Universidade de São Paulo. 
DAMANPOUR, F., SZABAT, K., EVAN, W. The relationship between types of innovation and organizational performance. Journal of Management Studies, v.26, n.6, p.587-601, 1989.

DARROCH, J. Knowledge management, innovation and firm performance. Journal of Knowledge Management, v.9, n.3, p.101-115, 2005.

DAVILA, G.A. Relações entre práticas de gestão do conhecimento, capacidade absortiva e desempenho: evidências do sul do brasil. Florianópolis, 2016. Tese (Doutorado em Engenharia e Gestão do Conhecimento) - Universidade Federal de Santa Catarina.

DAVILA, G.A., NORTH, K., VARVAKIS, G. How Brazilian textile enterprises learn to grow. Em: Competitive Strategies for Small and Medium Enterprises. Springer International Publishing, p. 241-254, 2016.

DAVILA, G.A., DURST, S., VARVAKIS, G. Knowledge Absorptive Capacity, Innovation, and Firm's Performance: Insights From the South of Brazil. International Journal of Innovation Management, v.22, n.2, 2018.

DESS, G., ROBINSON, R. Measuring organizational performance in the absence of objective measures: the case of the privately-held firm and conglomerate business unit. Strategic management journal, v.5, n.3, p.265-273, 1984.

DOMINGUEZ GONZALEZ, R., MARTINS, F., TOLEDO, J. Managing knowledge in a service provider: a network structure-based model. Journal of Knowledge Management, v.18, n.3, p.611-630, 2014.

FIESC - Federação das Indústrias do Estado de Santa Catarina. Panorama e Perspectivas dos Investimentos da Indústria Catarinense - 2015 a 2018 - 16. ed. Florianópolis: FIESC, 2016.

FIGUEIREDO, P. Embedding with multiple knowledge sources to improve innovation performance: the learning experience of Motorola in Brazil. Knowledge Management Research \& Practice, v.11, n.4, p.361-373, 2013.

FLEURY, A.; FLEURY, M. Aprendizagem e inovação organizacional: as experiências de Japão, Coréia e Brasil. São Paulo: Atlas, 1995.

FORNELL, C., LARCKER, D. Evaluating structural equation models with unobservable variables and measurement error. Journal of marketing research, v.18, n.1, p.39-50, 1981.

GEISSER, S. The predictive sample reuse method with applications. Journal of the American Statistical Association, v.70, n.350, p.320-328, 1975.

GEREFFI, G. Global Value Chains, Productive Development Policies and Job Creation. Lima: ILO Americas Technical Reports, 2017.

GLOET, M., TERZIOVSKI, M. Exploring the relationship between knowledge management practices and innovation performance. Journal of Manufacturing Technology Management, v.15, n.5, p.402-409, 2004.

GITHII, S. Knowledge management practices and innovation performance: a literature review. IOSR Journal of Business and Management, v.16, n.2, p.89-94, 2014.

GOEDHUYS, M., VEUGELERS, R. Innovation strategies, process and product innovations and growth: Firm-level evidence from Brazil. Structural Change and Economic Dynamics, v.23, n.4, p.516-529, 2012.

GRANT, R. Toward a knowledge-based theory of the firm. Strategic management journal, v.17, n.S2, p.109-122, 1996.

HAIR, J., BLACK, W., BABIN, B., ANDERSON, R., TATHAM, R. Multivariate data analysis. Upper Saddle River, NJ; Pearson Prentice Hall, 2006.

HENSELER, J., HUBONA, G., RAY, P. Using PLS path modeling in new technology research: updated guidelines. Industrial Management \& Data Systems, v.116, n.1, p.2-20. 2016.

HOUSE, R.; HANGES, P., JAVIDAN, M., DORFMAN, P., GUPTA, V. Culture, Leadership, and Organizations, The Globe Study of 62 Societies, Thousand Oaks: Sage, 2004.

HUANG, K., WU, J., LU, S., LIN, Y. Innovation and technology creation effects on organizational performance. Journal of Business Research, v.69, n.6, p.2187-2192, 2016.

IBGE. Brazil in figures 2014. Brasilia: IBGE, 2014.

INKINEN, H., KIANTO, A., VANHALA, M. Knowledge management practices and innovation performance in Finland. Baltic Journal of Management, v.10, n.4, p.432-455, 2015.

JACQUES, J.; REIS, C. Gestão estratégica do conhecimento baseada na construção de protocolos médico-assistenciais: o compartilhamento de ideias entre parcerias estratégicas como vantagem competitiva. RAI-Revista de Administração e Inovação, v. 4, n. 1, 2007. 
JANSEN, J., VAN DEN BOSCH, F., VOLBERDA, H. Exploratory innovation, exploitative innovation, and performance: Effects of organizational antecedents and environmental moderators. Management Science v.52, n.11, p.1661-1674, 2006.

JENNINGS, P., BEAVER, G. The performance and competitive advantage of small firms: a management perspective. International Small Business Journal, v.15, n.2, p.63-75, 1997.

JIMENEZ-JIMENEZ, D., SANZ-VALLE, R. Innovation, organizational learning, and performance. Journal of Business Research, v.64, n.4, p.408-417, 2011.

KIANTO, A.; ANDREEVA, T. Knowledge Management Practices and Results in Service-Oriented versus Product-Oriented Companies. Knowledge and Process Management, v. 21, n. 4, p. 221-230, 2014.

KIANTO, A.; HUSSINKI, H.; VANHALA, M. The Impact of Knowledge Management on the Market Performance of Companies. In: Knowledge Management in the Sharing Economy. Springer, Cham, 2018. p. $189-207$.

LÓPEZ-NICOLÁS, C., MEROÑO-CERDÁN, A. Strategic knowledge management, innovation and performance. International journal of information management. v. 31, n. 6, p. 502-509, 2011

NAGANO, M., STEFANOVITZ, J., VICK, T. Innovation management processes, their internal organizational elements and contextual factors: An investigation in Brazil. Journal of Engineering and Technology Management, v.33, p.63-92, 2014.

NOGUEIRA, R., ROSALES, F., BATALHA, M., ALCANTARA, R. Analyzing effects of external integration on innovations outcomes in large and non-large Brazilian food companies. British Food Journal, v.116, n.6, p.984-999, 2014.

NONAKA, I.; PELTOKORPI, V. Objectivity and subjectivity in knowledge management: a review of 20 top articles. Knowledge and process management, v.13, n.2, p.73-82, 2006.

NONAKA, I.; TAKEUCHI, H. The knowledge creation company: how Japanese companies create the dynamics of innovation. New York: Oxford University Press, 1995.

NORTH, K., DA SILVA NETO, E., DAVILA, G.A. Vencendo os desafios do crescimento: o método "aprender a crescer" para pequenas e médias empresas brasileiras. Navus-Revista de Gestão e Tecnologia, v.3, p.06-19, 2013.

NUNNALLY, J., BERNSTEIN, I. Psychometric theory. New York, NY: McGraw-Hill, 1994.

PAIVA, E., ROTH, A., FENSTERSEIFER, J. Organizational knowledge and the manufacturing strategy process: a resource-based view analysis. Journal of Operations Management, v.26, n.1, p.115-132, 2008.

PAIVA, E., REVILLA GUTIERREZ, E., ROTH, A. Manufacturing strategy process and organizational knowledge: a cross-country analysis. Journal of Knowledge Management, v.16, n.2, p.302-328, 2012.

PAVITT, K. Sectoral patterns of technical change: towards a taxonomy and a theory. Research policy, v.13, n.6, p.343-373, 1984.

PENG, M.W. Towards an institution-based view of business strategy. Asia Pacific Journal of Management, v. 19 , n. 2-3, p. 251-267, 2002.

PIETROBELLI, C., RABELLOTTI, R. Global Value Chains Meet Innovation Systems: Are There Learning Opportunities for Developing Countries? World Development, v.39, n.7, p.1261-1269, 2011.

PONCHIROLLI, O., FIALHO, F. Gestão estratégica do conhecimento como parte da estratégia empresarial. Revista da FAE, v. 8, n. 1, 2005.

RODRIGUES, S. B., GONZALEZ DUARTE, R., DE PADUA CARRIERI, A. Indigenous or imported knowledge in Brazilian management studies: A quest for legitimacy?. Management and Organization Review, v. 8, n. 1, p. 211-232, 2012.

ROMAN, D., PIANA, J., STIVAL PEREIRA, M., DE MELLO, N., ERDMANN, R. Fatores de competitividade organizacional. Brazilian Business Review, v.9, n.1, p. 27-46, 2012.

ROMIJN, H., ALBALADEJO, M. Determinants of innovation capability in small electronics and software firms in southeast England. Research policy, v.31, n.7, p.1053-1067, 2002.

SCHUMPETER, J. The explanation of the business cycle. Economica, n.21, p.286-311, 1927.

SEBRAE. Anuário do trabalho na micro e pequena empresa 2015. Brazilian Service of Support for Micro and Small Enterprises - SEBRAE, São Paulo, 2017. Retrieved from: https://m.sebrae.com.br/Sebrae/Portal\%20Sebrae/Anexos/anu\%C3\%A1rio\%20do\%20trabalho\%202015.pdf

SERGEEVA, A., ANDREEVA, T. Knowledge sharing research: bringing context back in. Journal of Management Inquiry, v. 25, n. 3, p. 240-261, 2016.

SPARKMAN, T. The factors and conditions for national human resource development in Brazil. European Journal of Training and Development, v.39 n.8, p.666-680, 2015.

STONE, M. Cross-validatory choice and assessment of statistical predictions. Journal of the royal statistical society. Series B (Methodological), p.111-147, 1974. 
STRATEGIC DIRECTION. Volvo's Latin American style: Lean production in Swedish truck giant's Brazilian plants shows how to combine best practice and local culture. Strategic Direction, v. 21, n.1, p.28-29, 2005.

TIDD, J., BESSANT, J. Managing innovation: integrating technological, market and organizational change, $3^{\text {rd }}$ edition. Sussex: John Wiley \& Sons, 2005.

WANG, G., TIAN, X., GENG, J., GUO, B. A process innovation knowledge management framework and its application. Advanced Materials Research, v.655-657, p.2299-2306, 2013.

WIJNANDS, J., VAN DER MEULEN, B., POPPE, K. Competitiveness of the European food industry. An Economic and Legal Assessment. Luxemburg: Office for Official Publications of the European Communities, 2007.

ZACK, M., MCKEEN, J., SINGH, S. Knowledge management and organizational performance: an exploratory analysis. Journal of knowledge management, v.13, n.6, p.392-409, 2009. 